\title{
Related Variety, Unrelated Variety and Regional Economic Growth
}

\section{Koen Frenken , Frank Van Oort \& Thijs Verburg}

To cite this article: Koen Frenken , Frank Van Oort \& Thijs Verburg (2007) Related Variety, Unrelated Variety and Regional Economic Growth, Regional Studies, 41:5, 685-697, DOI: 10.1080/00343400601120296

To link to this article: https://doi.org/10.1080/00343400601120296

曲 Published online: 27 Aug 2010.

Submit your article to this journal $\pi$

Џlll Article views: 6540

Q View related articles $₫$

4 Citing articles: 883 View citing articles ๔ 


\title{
Related Variety, Unrelated Variety and Regional Economic Growth
}

\author{
KOEN FRENKEN*, FRANK VAN OORT ${ }^{*} \dagger$ and THIJS VERBURG† \\ *Urban and Regional Research Centre Utrecht (URU) Section of Economic Geography, Faculty of Geosciences, Utrecht \\ University, PO Box 80115, NL-3508 TC Utrecht, the Netherlands.Email: k.frenken@geo.uu.nl \\ †Netherlands Institute for Spatial Research, PO Box 30314, NL-2500 GH The Hague, the Netherlands
}

(Received July 2005: in revised form May 2006)

Frenken K., Van Oort F. and Verburg T. (2007) Related variety, unrelated variety and regional economic growth, Regional Studies 41, 685-697. In economic theory, one can distinguish between variety as a source of regional knowledge spillovers, called Jacobs externalities, and variety as a portfolio protecting a region from external shocks. It is argued that Jacobs externalities are best measured by related variety (within sectors), while the portfolio argument is better captured by unrelated variety (between sectors). A methodology based on entropy measures is introduced to compute related variety and unrelated variety. Using data at the NUTS 3 level in the Netherlands for 1996-2002, it was found that Jacobs externalities enhance employment growth, while unrelated variety dampens unemployment growth. Productivity growth can be explained by traditional determinants including investments and research and development expenditures. Implications for regional policy follow.

Variety Growth Jacobs externalities Agglomeration economies Spillover Entropy

Frenken K., VAn OORT F. et Verburg T. (2007) La variété connexe, la variété sans rapport et la croissance économique régionale., Regional Studies 41, 685-697. Dans la théorie économique, on peut distinguer entre la variété comme la source des retombées de connaissance régionales, dites les effets externes de Jacob, et la variété comme un portefeuille qui protège la région des chocs externes. On affirme que l'on peut mieux mesurer les effets externes de Jacob à partir de la notion de variété connexe (au sein des secteurs), tandis que l'argument qui prône plutôt la notion de portefeuille est mieux saisi par la notion de variété sans rapport (entre les secteurs). On présente une méthodologie fondée sur des mesures d'entropie afin d'estimer la variété connexe et la variété sans rapport. A partir des données au niveau NUTS 3 auprès des Pays-Bas pour la période de 1996 à 2002, on trouve que les effets externes de Jacob augmentent la croissance de l'emploi, alors que la variété sans rapport atténue la croissance du chômage. La croissance de la productivité s'explique par des déterminants traditionnels, y compris l'investissement et les dépenses de recherche-développement. Il s'ensuit les implications pour la politique régionale.

Variété Croissance Effets externes de Jacob Economies d'agglomération Retombées Entropie

Frenken K., VAN OORT F. und Verbur G T. (2007) Zusammenhängende Vielfalt, nicht zusammenhängende Vielfalt und regionales Wirtschaftswachstum, Regional Studies 41, 685-697. In der Wirtschaftstheorie unterscheidet man zwischen der Vielfalt als Quelle regionaler Wissensübertragung (den so genannten Jacobs-Externalitäten) und der Vielfalt als Portfolio zum Schutz einer Region vor externen Erschütterungen. Wir stellen die These auf, dass sich die Jacobs-Externalitäten am besten anhand der zusammenhängenden Vielfalt (innerhalb von Sektoren) messen lassen, während sich das Portfolio-Argument besser durch nicht zusammenhängende Vielfalt (zwischen verschiedenen Sektoren) darstellen lässt. Mit Hilfe einer Methodologie auf der Grundlage entropischer Messungen ermitteln wir zusammenhängende Vielfalt und nicht zusammenhängende Vielfalt. Anhand von Daten auf dem NUTS 3-Niveau in den Niederlanden für den Zeitraum von 1996 bis 2002 stellen wir fest, dass die Jacobs-Externalitäten zu einem Anstieg des Beschäftigungsniveaus führen, während nicht zusammenhängende Vielfalt den Anstieg der Arbeitslosigkeit dämpft. Der Anstieg der Produktivität lässt sich durch traditionelle Determinanten wie Investitionen und Ausgaben für F\&E erklären. Im Anschluss werden die Konsequenzen für die Regionalpolitik beschrieben.

Vielfalt Wachstum Jacobs-Externalitäten Agglomerationswirtschaften Übertragung Entropie

Frenken K., Van Oort F. y Verburg T. (2007) Variedad relacionada, variedad no relacionada y el crecimiento económico regional, Regional Studies 41, 685-697. En la teoría económica, podemos distinguir entre la variedad como una fuente de desbordamientos de conocimiento regionales, llamados externalidades Jacobs, y la variedad como una cartera que protege una región de choques externos. Sostenemos que las externalidades Jacobs se miden mejor según la variedad relacionada (dentro de los sectores), mientras que el argumento de la cartera se capta mejor con una variedad no relacionada (entre sectores). Para calcular la variedad relacionada y la variedad no relacionada, introducimos una metodología basada en las medidas de entropía. Usando datos en el nivel NUTS 3 en los Países Bajos para el periodo 1996-2002, observamos que las externalidades Jacobs aumentan el crecimiento de 
empleo mientras que la variedad no relacionada desestimula el crecimiento de desempleo. El crecimiento de productividad puede explicarse mediante determinantes tradicionales incluyendo las inversiones y los gastos en I + D. También explicamos las implicaciones para la política regional.

Variedad Crecimiento Externalidades Jacobs Economías de aglomeración Desbordamiento Entropía

JEL classifications: D62, O18, R11

\section{INTRODUCTION}

The relationship between variety and economic development has been a neglected research area in economics. For long, economic theory has focused on explaining economic growth by a combination of growth in inputs and efficiency improvements (SOLOW, 1957). The underlying qualitative nature of economic development, e.g. in terms of the variety of sectors or the variety of technologies, has been addressed only rarely.

One can distinguish between three types of relationships between variety and economic development. The first approach centres on variety, spillovers and growth, which has become a central theme in what is called new growth theory. It has been argued that, apart from spillovers occurring between firms within a sector, spillovers also occur between sectors. Following this argument, the present variety in an economy can be an additional source of economic growth (JACOBS, 1969; Glaeser et al., 1992; VAn OORT, 2004). This means that not only the stock of inputs affects growth, but also the precise composition in a qualitative sense. And since spillovers are geographically bounded, differences in regional growth should be related to qualitative differences in an economy's composition at the regional level. Only some sectors are complementary in that their joint presence within an economy causes additional growth. A region specializing in a particular composition of complementary sectors will experience higher growth rates than a region specializing in sectors that do not complement each other.

A second way to relate variety to regional economic development, and more specifically to unemployment, is to view variety as a portfolio strategy to protect a region from external shocks in demand (ATTARAN, 1986; Haug, 2004). In this context, one also speaks of regional diversification analogous to corporate diversification as a risk-spreading strategy. A high sector variety of a regional economy implies that a negative shock in demand for any of these sectors will only have mild negative effects on growth and employment. By contrast, a region specializing in one sector, or a group of sectors with correlated demand, runs the risk of a serious slowdown in growth and high rates of unemployment as a result of a demand shock.

Finally, a third type of relationship between variety and economic development concerns the long-term effect of variety on the economic system. PASINetTi (1993) argued that an economy that does not increase the variety of sectors over time will suffer from structural unemployment, and will ultimately stagnate. In this view, the development of new sectors in an economy is required to absorb labour that has become redundant in pre-existing sectors. This labour has become redundant due to a combination of productivity increases and demand saturation in pre-existing sectors, characterizing the product lifecycle dynamics in each sector. These processes underlying long-term growth have also geographical implications, as new sectors typically emerge in urban areas, while the older sectors are more dominant in rural areas. This means that labour becomes redundant primarily in rural areas, while new employment is primarily created in urban areas. This imbalance is counteracted by labour migration from rural to urban areas and by firm migration in the opposite direction. The following text, however, will focus mainly on the first two approaches as the data cover only a short period of time (seven years), whereas a test of Pasinetti's thesis would require a longer time series.

Another issue closely related but analytically distinct from the issue of variety and regional economic growth is the relationship between variety and urbanization. There is a wide agreement that variety is positively related to the degree of urbanization, the reason being that a variety of products and sectors can only be sustained with sufficient local demand, both for intermediate inputs and final products. With urbanization being positively related to variety, and variety being positively related to economic growth, urbanization will generally have a positive impact on economic growth. However, it is important to distinguish, both theoretically and empirically, between urbanization as a source of economic growth and variety per se as a source of economic growth (i.e. when controlling for urbanization).

Approaching the question of regional economic development from the concept of variety, the paper will not provide a comprehensive review of regional growth theory. Rather, it will zoom in on those theories that have something to say about the role of variety in economic growth. Following the two approaches distinguished above, theories of spillovers including the new growth theory and the economics of agglomeration (the second section) and portfolio theory and regional diversification (the third section), respectively, will be discussed. Data and measurement issues will be discussed (the fourth section), as well as the empirical analysis of regional employment growth, productivity growth and unemployment growth for Dutch regions will be (the fifth section). Concluding remarks and policy reflections end the paper. ${ }^{1}$ 


\section{ECONOMICS OF AGGLOMERATION}

The central idea underlying the economics of agglomeration holds that the clustering of economic activity occurs because firms experience some form of benefit from locating near one another. A broad definition of agglomeration economies is that it concerns economies from which a firm can benefit by being located at the same place as one or more other firms. Four sources of agglomeration economies have been distinguished:

(1) Internal increasing returns to scale. These may occur in a single firm due to production cost efficiencies realized by serving large markets (KRUGMAN, 1991). There is nothing inherently spatial in this concept other than that the existence of a single large firm in space implies a large local concentration of factor employment.

(2) External economies available to all local firms within the same sector: localization economies.

(3a) External economies available to all local firms irrespective of sector and arising from urban size and density: urbanization economies.

(3b) External economies available to all local firms stemming from a variety of sectors: Jacobs externalities (JACOBS, 1969).

The following discussion limits itself to external economies. Localization economies (2) usually take the form of what are called Marshallian (technical) externalities whereby the productivity of labour in a given sector in a given city is assumed to increase with total employment in that sector. Marshallian externalities arise from three sources: labour market pooling, the creation of specialized suppliers, and the emergence of knowledge spillovers (FESER, 2002; HENDERSON, 2003).

Urbanization economies (3a) reflect external economies passed to enterprises as a result of savings from the large-scale operation of the agglomeration or city as a whole and independent from industry structure. Relatively more populous localities are also more likely to house universities, industry research laboratories, trade associations and other knowledge generating organizations. It is the dense presence of these organizations (not solely economic in character, but also social, political and cultural) that supports the production and absorption of know-how, stimulating innovative behaviour, and which contributes to differential rates of interregional growth. The diverse industry mix in an urbanized locality also improves the opportunities to interact, copy, modify, and recombine ideas, practices and technologies across industries giving rise to Jacobs externalities (3b). Important innovations stem from the recombination of knowledge present in different industries. Geographical proximity between firms in different industries renders such recombination more likely to occur, in particular if firms also operate under similar institutional conditions. The functional specialization of firms in heterogeneous industries in close proximity of each other is supposed to generate spatial interdependencies and generates benefits (and costs such as congestion) for everyone in that specific location (QUigLY, 1998). Thus, variety in itself may be an extra source of knowledge spillovers and innovation.

Given the different potential sources of spillovers, an important empirical question holds whether these spillovers occur primarily when a region is specialized in a few sectors (localization economies), or diversified into a large variety of sectors (Jacobs externalities), or whether it is primarily related to city size and density per se (urbanization economies). In principle, all three types of agglomeration economies can occur as a result of spillovers, as a firm can learn from firms in the same industry (localization economies), from firms in other industries (Jacobs externalities), or from a concentration of actors other than firms, including consumers, universities, and governments (urbanization economies). Focusing on the question whether regional growth benefits most from localization economies or Jacobs externalities, the issue at hand is one of composition. As the amount of spillovers differs, both within each sector, and between each pair of sectors, the question is which precise composition of sectors in a regional economy creates most spillovers.

The distinction between the different sources of spillovers bears important implications on theorizing, because different types of spillovers are expected to lead to qualitatively different types of benefits. Localization economies are expected to spur incremental innovation and process innovation, as the spillovers originate from similar firms producing similar products. The impact of localization economies is thus expected to filter down primarily to productivity increases. By contrast, Jacobs externalities are expected to facilitate particularly radical innovation and product innovation as knowledge and technologies from different sectors are recombined leading to complete new products or technologies (compare Schumpeter's concept of 'Neue Kombinationen'). And, since radical innovations and product innovation lead to the creation of new markets and employment, rather than productivity increases, their impact may be very different from the incremental and process innovations caused by localization economies. These qualitative differences in the types of innovation are also taken up by evolutionary trade theory and evolutionary growth theory (Vernon, 1966; Saviotti and Pyka, 2004).

Given that different types of spillover effects have potentially different effects on innovation and growth, one should be careful in selecting variables in an empirical research design. When analysing the impact of agglomeration economies on productivity growth, one can expect localization economies to be important, while Jacobs externalities are expected to be important to explain differences in employment growth. Thus, both localization economies and Jacobs externalities are all expected to contribute to regional economic 
development, but in different ways. This leads the authors to formulate the following hypotheses:

- Hypothesis 1: Jacobs externalities are positively related to employment growth.

- Hypothesis 2: Localization economies are positively related to productivity growth.

\section{RELATED VERSUS UNRELATED VARIETY}

A second theory relating variety to economic growth concerns portfolio theory, a concept from business economics (MOnTGOMerY, 1994). Portfolio theory is usually applied to the valuation of a collection of assets, or to the impact of product diversification on corporate profitability and growth. Whatever the context of application, the concept of portfolio amounts to saying that variety reduces risk. Placing bets on more than one horse reduces the risk of high losses (although it also reduces the probability of high profits).

The extent to which a portfolio reduces risk is dependent on the correlation between economic outcomes associated with each of the elements within a portfolio. For example, a firm that diversifies its sales into 20 different products with correlated demand (say, 20 different holiday destinations in Greece) will not substantially reduce the risk of going bankrupt as a sudden fall in demand will hit all 20 products. By contrast, a firm that diversifies into only ten different products with uncorrelated demand will be more effective in reducing risk as a fall in demand in one product is most likely to be compensated by a rise in demand for another product.

The sectoral composition of a regional economy can be approached in a way analogous to corporate diversification in product portfolios. Regional variety can be considered a portfolio strategy to protect regional income from sudden sector-specific shocks in demand (also called asymmetric shocks that hit only one or few sectors, such as oil price shocks, a trade war, a radical innovation). This will especially protect labour markets, and thus prevent sticky unemployment to occur. Even if inter-regional labour mobility is high preventing unemployment to occur, asymmetric shocks reduce economic growth as agglomeration economies and the tax base deteriorate (KRUGMAN, 1993). Following this reasoning, industrial variety at the regional level would reduce regional unemployment and promote regional economic growth, while specialization would increase the risk of unemployment and a growth slowdown.

A central question is whether related or unrelated diversification is most rewarding for stability and growth. It can be expected that related industries more often (though, again, not as a rule) have correlated demand shocks. Therefore, spreading risk over unrelated sectors is to be preferred from the viewpoint of a portfolio strategy. However, one should also take into account the possible benefits from related diversification. Analogous to economies of scope at the firm level, one expects knowledge spillovers within the region to occur primarily among related sectors, and only to a limited extent among unrelated sectors. In terms of agglomeration theory, Jacobs externalities are expected to be higher in regions with a related variety of sectors than in regions with an unrelated variety of sectors.

The effects of related and unrelated sector variety, therefore, are expected to differ. Unrelated variety protects a region best against external asymmetric shocks in demand and thus against rising unemployment. By contrast, related variety in a sector is expected to be beneficial for Jacobs externalities in the form of knowledge spillovers, thus enhancing growth and employment (as already stated in hypothesis 1). This leads us to the following additional hypothesis:

- Hypothesis 3: Unrelated variety is negatively related to regional unemployment growth.

\section{HYPOTHESIS TESTING FOR REGIONAL GROWTH IN THE NETHERLANDS}

Data were collected at the NUTS 3 level. The choice of NUTS 3 as the spatial unit of analysis was motivated by the wish to deal with labour market regions, which are regarded as the most relevant unit of analysis in agglomeration research. In the Netherlands, the NUTS 3 level is commonly associated with spatial labour markets. A recent study on functional regions in the Netherlands by BONGAERTS et al. (2004) confirmed that the functional coherence of the NUTS 3 classification is indeed statistically not less coherent than the classification that can be obtained by empirical computation.

\section{Dependent variables}

- EMPLOYMENT GROWTH (1996-2002): computed as percentage growth over fulltime employee equivalents (1996-2002) using data from Statistics Netherlands (CBS) and includes all economic activities except agriculture.

- PRODUCTIVITY GROWTH (1996-2001): computed as percentage growth (1996-2001) and provided by the University of Groningen (BROERSMA and OOSTERHAVEn, 2004).

- UNEMPLOYMENT GROWTH (1996-2002): concerns labour productivity and is computed as percentage growth (1996-2002) using data from Statistics Netherlands (CBS).

- INACTIVITY GROWTH (1996-2002): computed as percentage growth (1996-2002) and computed from data from Statistics Netherlands (CBS). Inactivity growth is used below as an alternative measure for unemployment growth. Inactivity data include both 
unemployment numbers and the numbers of physically disabled workers (often seen as a hidden form of unemployment; Broersma and VAN DiJK, 2002).

\section{Independent variables}

The dependent variable is expressed below as a function of initial conditions in the independent variables, except for some variables. This procedure has been necessary given that data were not available for all years. Because of non-normality of the distribution of some variables (indicated by either the skewness test or the Kolmogorov-Smirnov test), these were log-transformed. Some variables were also corrected for outliers. ${ }^{2}$ The following section uses standardized scores ( $z$-values with average zero and a standard deviation of 1 ) of all variables in order to assess the relative effect of independent variables. After corrections and transformations, these variables are normally distributed.

- UNRELATED VARIETY (1996).

- RELATED VARIETY (1996).

As explained above, the concept of related variety holds that some sectors are more related than others, and will generate relatively more Jacobs externalities. To examine empirically the effect of related or unrelated variety is not a trivial matter, and sophisticated methodologies of diversification and inter-sectoral spillovers are relatively scarce (JAFFE, 1986; TEECE et al., 1994; Verspagen, 1997; Breschi et al., 2003).

One methodology, which has specifically been applied in the context of related and unrelated diversification, both at the firm (JACQUEMIN and BERRY, 1979) and regional levels (WASYLENKO and ERICKSON, 1978; Kort, 1981; AtTARAN, 1986), concerns the entropy measure. The main advantage of the entropy measure, and the reason for its use in the context of diversification, is that entropy can be decomposed at each sectoral digit level. The decomposable nature of entropy implies that variety at several digit levels can enter a regression analysis without necessarily causing collinearity (THeIL, 1972; JACQUEMIN and BERRY, 1979; Attaran, 1986). The following computes entropy using employment data, which are available for the Netherlands at the five-digit level from the LISA database (VAN OORT, 2004). Unrelated variety per region is indicated by the entropy of the two-digit distribution; related variety is indicated by the weighted sum of the entropy at the five-digit level within each two-digit class.

Formally, let all five-digit sectors $i$ fall exclusively under a two-digit sector $S_{g}$, where $g=1, \ldots, G$. One can derive the two digit shares, $P_{g}$, by summing the five-digit shares $p_{i}$ :

$$
P_{g}=\sum_{i \in S_{g}} p_{i}
$$

The entropy at the two-digit level, or unrelated variety (UV), is given by:

$$
\mathrm{UV}=\sum_{g=1}^{G} P_{g} \log _{2}\left(\frac{1}{P_{g}}\right)
$$

Related variety (RV), as the weighted sum of entropy within each two-digit sector, is given by:

$$
\mathrm{RV}=\sum_{g=1}^{G} P_{g} H_{g}
$$

where:

$$
H_{g}=\sum_{i \in S_{g}} \frac{p_{i}}{P_{g}} \log _{2}\left(\frac{1}{p_{i} / P_{g}}\right)
$$

As explained first by TheiL (1972, pp. 20-22) and later by JACQUEMIN and BERRY (1979) and ATTARAN (1986), the decomposable nature of the entropy measure implies that five-digit entropy is equal to the sum of two-digit entropy (unrelated variety) and the weighted sum of five-digit entropy within each twodigit class (related variety).

As argued above, the present authors consider related variety to be the indicator for Jacobs externalities because it measures the variety within each of twodigit classes. It is expected that the economies arising from variety are especially strong between subsectors, as knowledge spills over primarily between firms selling related products. By contrast, unrelated variety measures the extent to which a region is diversified in very different types of activity. This type of variety is expected to be instrumental in avoiding unemployment.

The maps of related and unrelated variety provided in Fig. 1 present two very different regional patterns for related variety and unrelated variety. As is clear from the maps, variety at high levels of aggregation shows little resemblance with variety at low levels, which strongly suggests that the choice of sector aggregation is not trivial. The absence of positive correlation between related and unrelated variety further supports this fact (correlation $=-0.046$ )

- LOS-INDEX (1996). Localization economies are associated with the concentration of a particular sector in a region. Often, this type of economy is captured by specialization indicators (GLAESER et al., 1992; VAN OORT, 2004; VAN Stel and Nieuwenhuijsen, 2004). ${ }^{3}$ The Los-index (Los, 2000) captures the technological relatedness between industrial sectors by computing the similarity between two sectors' input mix from input-output tables. As input mixes reflect 

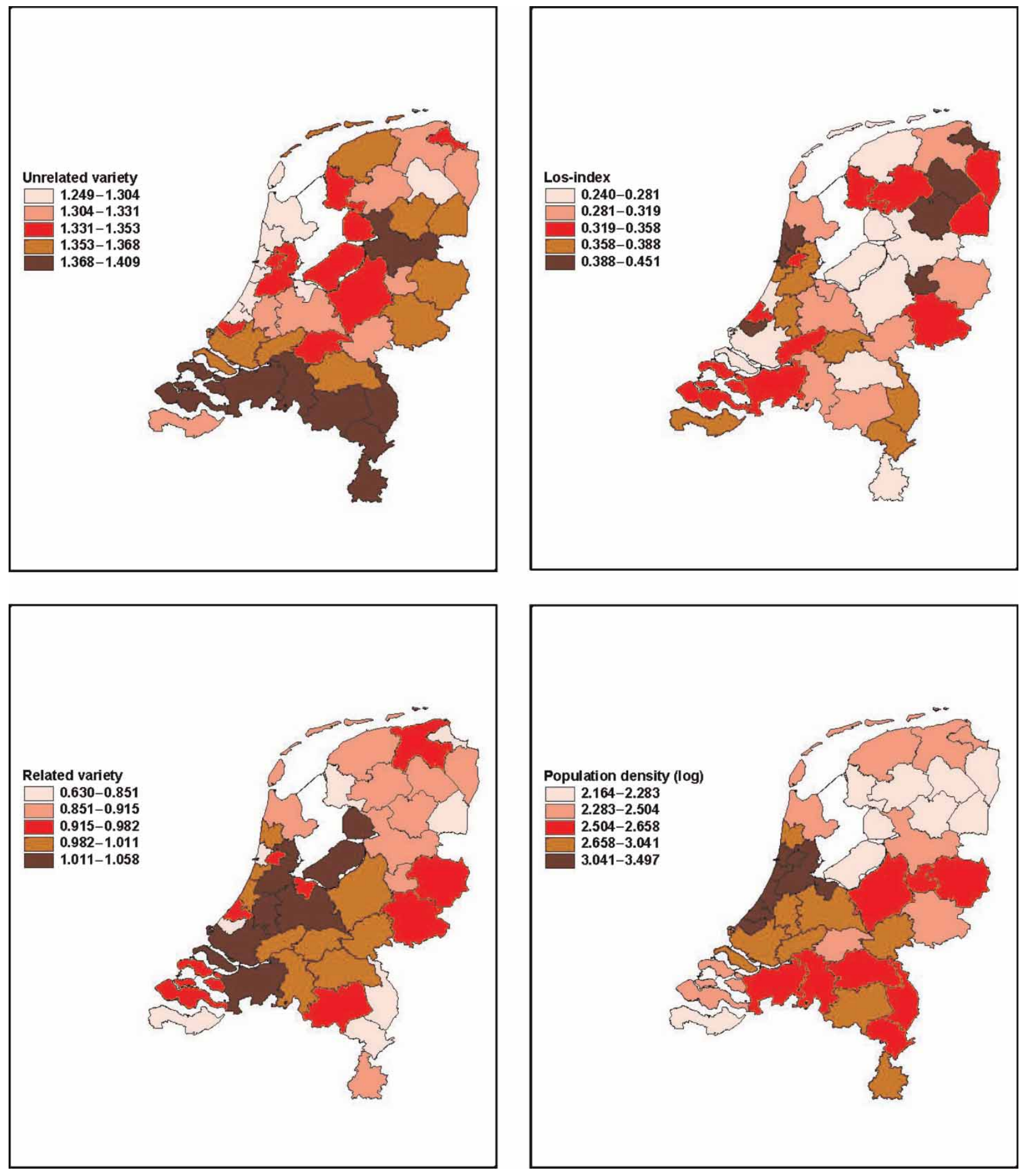

Fig. 1. Maps of the four main independent variables

production technologies, a high similarity in input mixes of two sectors implies a small 'technological distance' between two sectors, and a high amount of spillovers. Conversely, two industries with very different input mixes are technologically distant, and, consequently, will hardly mutually benefit from spillovers. Technological similarity within a sector is by definition equal to 1 , as jobs within the same sector are assumed to yield the highest amount of spillovers (underlying the concept of localization economies). This index is considered here to be a better proxy for localization economies than specialization indicators because (1) it takes into account both the regional concentration of a single industry and of technologically related industries, and (2) it is not a relative specialization 
measure, but is based on absolute concentration of particular sectors in a region.

The data on technological similarity based on national input-output data are provided by Bart Los from the University of Groningen (Los, 2000). The present authors have chosen to apply the measure only to industrial sectors and knowledgeintensive service sectors because the concept of knowledge spillovers is known to be strongest in these sectors (including all other services would have substantially lowered the variance in the Losindex). The data consist of a matrix of similarity values for each pair of sectors ranging from zero (no inputs in common) to 1 (all inputs in common). For a region $k$, the number of jobs was multiplied for each pair of sectors. This number is multiplied by the corresponding similarity value between the two sectors. This is repeated for all pairs of sectors. The sum of the pairwise multiplications is finally divided by the maximum possible value (which is obtained if all sectors would have perfect similarity). Let $s_{i k}$ and $s_{j k}$ be the number of jobs in sectors $i$ and $j$, respectively; and $a_{i j}$ be the technological similarity value between sectors $i$ and $j$, then the Los-index is computed as follows:

$$
\operatorname{Los}_{k}=\frac{\sum_{i=1}^{n} \sum_{j=1}^{n}\left(s_{i k} \cdot s_{j k} \cdot a_{i j}\right)}{\sum_{i=1}^{n} \sum_{j=1}^{n}\left(s_{i k} \cdot s_{j k}\right)}
$$

This index ranges from the minimum value $(1 / n)$ to its maximum value of 1 . Note that as the technological similarity within a sector is by definition equal to 1 (the diagonal in the similarity matrix), a region that is fully specialized in one sector always acquires the maximum possible value. In all other cases, the Losindex will lie between the minimum and maximum values (Fig. 1). A value of 1 indicates the presence of one ideal type of a cluster of either industry or a set of technologically equivalent industries, in which the amount of localization economies in a region is fully maximized. Also, note that it does not measure related variety, because its value increases with specialization in one industry.

- POpUlation Density (LOG) (1996). Population density is used as a proximate indicator of urbanization economies stemming from a large concentration of economic activity per se irrespective of its composition (Fig. 1).

\section{Control variables}

In line with Glaeser et al. (1992), VAN OORT (2004) and Broersma and Oosterhaven (2004), control variables were introduced that potentially co-determine regional employment, productivity and unemployment growth. This concerns average wage levels, investment levels per full-time equivalent (fte), the capital-labour ratio growth, R\&D expenditures per fte, business area growth, dwellings growth, the regional level of competition between firms (measured by average firm size), the level of human capital (measured by the degrees of education of the working labour force), and the level of specialization in traditional manufacturing sectors. For a full explanation of the variables, see FrENKEN et al. (2004).

\section{RESULTS}

This section starts from theoretically based baseline models in which the most relevant variables, which are the indicators related to the different types of agglomeration economies, are included: unrelated variety (to test for the portfolio effect), related variety (to test for Jacobs externalities), the Los-index (to test for localization economies), and population density (to control for pure urbanization economies). Including all these variables allows one to assess the relative effect of different potential sources of agglomeration economies (correlations between these four variables are all $<0.5)$.

As the main control variables, it has been chosen to include the variables investment and $\mathrm{R} \& \mathrm{D}$. In addition, when dealing with productivity growth and unemployment, the capital-labour ratio growth was included as a control. There are both theoretical (SOLOw, 1957) and empirical (Broersma and Oosterhaven, 2004; KIM, 1997) reasons to assume that productivity growth is very sensitive to this ratio as it increases the amount of capital per worker. Concerning unemployment, an increase in the ratio between capital and labour may indicate labour-saving technological change, and thus may raise unemployment. Finally, also included in the baseline model explaining unemployment growth was the wage variable because regions with higher relative wage levels are expected to experience higher unemployment, ceteris paribus. All other variables are added on a one-by-one basis to the baseline model to assess whether the specification of the model improves. If so, these variables are shown in the results.

The Breusch-Pagan test for heteroskedasticity reveals that all specifications in the Tables $1-3$ are homoskedastic. The fact that heteroskedasticity is not a problem in any of the estimations indicates that over the 40 regions of observations no structural diverging error terms in classes of regions (regimes) are present.

\section{Results for employment growth}

Table 1 provides the results for EMPLOYMENT GROWTH as the dependent variable. Model 1 specifies 
Table 1. Dependent variable: EMPLOYMENT GROWTH

\begin{tabular}{|c|c|c|c|c|c|c|c|}
\hline & (1) OLS & (1a) OLS, 1996-2001 & (1b) OLS, 1997-2002 & (2) OLS & (3) OLS & (4) OLS & (5) OLS (WA) \\
\hline CONSTANT & $0.104(0.751)$ & $0.097(0.692)$ & $0.096(0.666)$ & $0.122(1.080)$ & $0.088(0.665)$ & $0.104(0.871)$ & $0.101(0.657)$ \\
\hline UNRELATED VARIETY & $-0.045(-0.281)$ & $-0.036(-0.226)$ & $-0.113(-0.686)$ & $-0.091(-0.696)$ & $-0.079(-0.516)$ & $0.134(0.916)$ & $0.126(0.622)$ \\
\hline RELATED VARIETY & $0.638^{* * *}(3.914)$ & $0.565^{* * *}(3.443)$ & $0.579^{* * *}(3.429)$ & $0.461^{* * *}(3.321)$ & $0.546^{* * *}(3.367)$ & $0.519^{* * *}(3.589)$ & $0.513^{* *}(2.598)$ \\
\hline LOS-INDEX & $-0.124(-0.738)$ & $-0.213(-1.261)$ & $-0.143(-0.824)$ & $0.029(0.203)$ & $-0.163(-1.010)$ & $-0.043(-0.297)$ & $-0.507^{* * *}(-2.882)$ \\
\hline POPULATION DENSITY (LOG) & $-0.266(-1.412)$ & $-0.215(-1.135)$ & $-0.242(-1.237)$ & $-0.649^{* * *}(-3.653)$ & $-0.193(-1.050)$ & $-0.125(-0.746)$ & $-0.079 *(-1.717)$ \\
\hline INVESTMENT (LOG) & $0.399^{* * *}(3.038)$ & $0.354^{* *}(2.675)$ & $0.366^{* *}(2.684)$ & $0.090(0.693)$ & $0.475^{* * *}(3.625)$ & $0.284^{* *}(2.408)$ & $-0.039(-0.607)$ \\
\hline $\mathrm{R} \& \mathrm{D}(\mathrm{LOG})$ & $0.228(1.473)$ & $0.192(1.232)$ & $0.246(1.535)$ & $0.151(1.185)$ & $0.157(1.031)$ & $0.040(0.277)$ & $-0.039(-0.534)$ \\
\hline WAGE & & & & $0.718^{* * *}(4.241)$ & & & \\
\hline BUSINESS AREA GROWTH (LOG) & & & & & $0.306^{*}(2.032)$ & & \\
\hline DWELLINGS GROWTH (LOG) & & & & & & $0.408^{* * *}(3.526)$ & \\
\hline$R^{2}$ & 0.512 & 0.488 & 0.456 & 0.688 & 0.568 & 0.649 & 0.449 \\
\hline Adjusted $R^{2}$ & 0.424 & 0.395 & 0.357 & 0.620 & 0.474 & 0.572 & 0.348 \\
\hline Lagrange Multiplier (error) & $3.416(0.065)$ & $2.297(0.130)$ & $2.995(0.084)$ & $2.779(0.095)$ & $1.203(0.272)$ & $0.829(0.363)$ & $0.046(0.829)$ \\
\hline Lagrange Multiplier (lag) & $2.197(0.138)$ & $1.731(0.188)$ & $1.919(0.166)$ & $4.208(0.040)$ & $1.639(0.201)$ & $2.308(0.129)$ & $0.110(0.740)$ \\
\hline Breusch-Pagan test & $9.428(0.151)$ & $10.429(0.108)$ & $11.243(0.081)$ & $11.560(0.116)$ & $7.336(0.395)$ & $5.039(0.655)$ & $6.849(0.335)$ \\
\hline
\end{tabular}

Notes: $t$-Values are in parentheses (except for Lagrange Multiplier test statistics and Breusch-Pagan test statistics, where $p$-values are shown). WA for window average variables (ANSELIN, 1988). Lagrange Multiplier tests for spatial dependence (lag and error) use second-order contiguity matrices. First-order contiguity is never significantly attached to the employment growth models.

Significant at the ${ }^{* * *} 0.01,{ }^{* *} 0.05$ and ${ }^{*} 0.10$ levels. 
Table 2. Dependent variable: PRODUCTIVITY GROWTH

\begin{tabular}{|c|c|c|c|c|c|}
\hline & (1) OLS & $\begin{array}{c}\text { (1a) OLS, } \\
1996-2000\end{array}$ & $\begin{array}{c}(1 \mathrm{~b}) \mathrm{OLS} \\
1997-2001\end{array}$ & (2) Spatial lag & (3) OLS (WA) \\
\hline CONSTANT & $-0.043(-0.412)$ & $-0.037(-0.349)$ & $-0.041(-0.352)$ & $-0.077(-0.886)$ & $0.006(0.038)$ \\
\hline UNRELATED VARIETY & $-0.061(-0.505)$ & $-0.008(-0.066)$ & $0.019(0.139)$ & $0.008(0.081)$ & $-0.080(-0.406)$ \\
\hline RELATED VARIETY & $-0.273^{* *}(-2.217)$ & $-0.264^{* *}(-2.114)$ & $-0.104(-0.762)$ & $-0.257^{* *}(-2.552)$ & $-0.318^{*}(-1.693)$ \\
\hline LOS-INDEX & $-0.084(-0.645)$ & $0.044(0.332)$ & $0.070(0.481)$ & $-0.088(-0.824)$ & $0.094(0.522)$ \\
\hline $\begin{array}{l}\text { POPULATION DENSITY } \\
\quad(\mathrm{LOG})\end{array}$ & $-0.092(-0.642)$ & $-0.145(-0.991)$ & $-0.080(-0.505)$ & $-0.131(-1.103)$ & $-0.007(-0.149)$ \\
\hline INVESTMENT (LOG) & $0.184 *(1.860)$ & $0.134(1.334)$ & $0.300^{* *}(2.731)$ & $0.201^{* *}(2.460)$ & $0.059(0.843)$ \\
\hline $\mathrm{R} \& \mathrm{D}(\mathrm{LOG})$ & $0.398^{* * *}(3.388)$ & $0.431^{* * *}(3.616)$ & $0.385^{* * *}(2.964)$ & $0.408^{* * *}(4.239)$ & $0.152^{* *}(2.199)$ \\
\hline C-L RATIO GROWTH & $0.705^{* * *}(6.165)$ & $0.712^{* * *}(6.134)$ & $0.651^{* * *}(5.139)$ & $0.761 * * *(8.110)$ & $0.195^{* *}(2.468)$ \\
\hline $\begin{array}{l}\text { W_PRODUCTIVITY } \\
\text { GROWTH }\end{array}$ & & & & $-0.418^{* * *}(-2.725)$ & \\
\hline$R^{2}$ & 0.648 & 0.637 & 0.568 & 0.682 & 0.368 \\
\hline Adjusted $R^{2}$ & 0.571 & 0.558 & 0.473 & 0.706 & 0.230 \\
\hline Maximum likelihood & -35.374 & -35.982 & -39.482 & -32.605 & -47.075 \\
\hline Lagrange Multiplier (error) & $1.933(0.164)$ & $0.045(0.831)$ & $0.174(0.676)$ & & $7.280(0.007)$ \\
\hline Lagrange Multiplier (lag) & $4.316(0.038)$ & $0.755(0.385)$ & $0.030(0.862)$ & & $5.177(0.023)$ \\
\hline Likelihood ratio test & & & & $5.537(0.019)$ & \\
\hline Breusch-Pagan test & $3.776(0.805)$ & $4.235(0.752)$ & $12.251(0.093)$ & $2.914(0.893)$ & $8.082(0.325)$ \\
\hline
\end{tabular}

Notes: $t$-Values are in parentheses (except for Lagrange Multiplier test statistics and Breusch-Pagan test statistics, where $p$-values are shown). WA for window average variables (ANSELIN, 1988). Lagrange Multiplier tests for spatial dependence (lag and error) use first-order contiguity matrices. Significant at the ${ }^{* * *} 0.01, * * 0.05$ and $* 0.10$ levels.

the ordinary least-squares (OLS) baseline model. From the results, it can be concluded that the main hypothesis is confirmed: related variety as an indicator for Jacobs externalities is indeed positively and significantly related to employment growth. Since $z$-values were used, the results also show that related variety contributes most to employment growth. Furthermore, investment as a control variable has the expected sign. Interestingly, population density has no significant effect on employment growth suggesting that it is not urbanization per se but related variety that contributes to job creation. Put differently, cities do not create jobs 'automatically'. Rather, related variety is responsible for job creation, which is often, but not necessarily, highest in cities. Models $1 \mathrm{a}$ and $1 \mathrm{~b}$ test for the robustness of model 1 by substituting the dependent variable, employment growth during 1996-2002, by the same variable for different periods (1997-2002) and

Table 3. Dependent variable: UNEMPLOYMENT GROWTH

\begin{tabular}{|c|c|c|c|c|c|}
\hline & (1) OLS & $\begin{array}{c}\text { (1a) OLS, } \\
1996-2001\end{array}$ & $\begin{array}{c}\text { (1b) OLS, } \\
1997-2002\end{array}$ & $\begin{array}{c}\text { (1c) OLS, } \\
\text { (including disabled) }\end{array}$ & (2) OLS (WA) \\
\hline CONSTANT & $0.021(0.146)$ & $-0.009(-0.055)$ & $0.090(0.581)$ & $0.029(0.198)$ & $-0.211(-1.362$ \\
\hline UNRELATED VARIETY & $-0.395^{* *}(-2.338)$ & $-0.044(-0.226)$ & $-0.402^{* *}(-2.238)$ & $-0.416^{* *}(-2.493)$ & $-0.118(-0.610)$ \\
\hline RELATED VARIETY & $0.031(0.173)$ & $0.182(0.869)$ & $0.081(0.425)$ & $0.099(0.556)$ & $-0.394^{*}(-1.824)$ \\
\hline LOS-INDEX & $0.156(0.829)$ & $0.112(0.510)$ & $0.382^{*}(1.904)$ & $0.015(0.078)$ & $0.405^{* *}(2.297)$ \\
\hline $\begin{array}{l}\text { POPULATION DENSITY } \\
\quad(\text { LOG })\end{array}$ & $-0.569^{* *}(-2.440)$ & $-0.057(-0.209)$ & $-0.564^{* *}(-2.273)$ & $-0.484^{* *}(-2.102)$ & $-0.224^{* * *}(-3.509)$ \\
\hline INVESTMENT (LOG) & $-0.176(-1.045)$ & $0.236(1.210)$ & $-0.036(-0.204)$ & $-0.189(-1.138)$ & $-0.199^{* *}(-2.570)$ \\
\hline R\&D (LOG) & $0.394 * *(2.376)$ & $0.026(0.135)$ & $0.259(1.474)$ & $0.490^{* * *}(2.991)$ & $-0.003(-0.037)$ \\
\hline WAGE & $0.383^{*}(1.742)$ & $-0.166(-0.652)$ & $0.409^{*}(1.754)$ & $0.349(1.609)$ & $0.401^{* * *}(3.908)$ \\
\hline C-L RATIO GROWTH & $0.299^{*}(1.866)$ & $0.145(0.780)$ & $0.482^{* * *}(2.834)$ & $0.009(0.058)$ & $0.119(1.519)$ \\
\hline$R^{2}$ & 0.333 & 0.102 & 0.386 & 0.349 & 0.428 \\
\hline Adjusted $R^{2}$ & 0.161 & 0.000 & 0.228 & 0.181 & 0.280 \\
\hline Lagrange Multiplier (error) & $0.971(0.324)$ & $0.006(0.940)$ & $0.209(0.648)$ & $0.188(0.665)$ & $3.861(0.049)$ \\
\hline Lagrange Multiplier (lag) & $1.210(0.271)$ & $0.034(0.853)$ & $0.372(0.542)$ & $0.335(0.563)$ & $3.218(0.073)$ \\
\hline Breusch-Pagan test & $7.319(0.503)$ & $6.370(0.606)$ & $8.190(0.415)$ & $6.144(0.523)$ & $2.989(0.934)$ \\
\hline
\end{tabular}

Notes: $t$-Values are in parentheses (except for Lagrange Multiplier test statistics and Breusch-Pagan test statistics, where $p$-values are shown). WA for window average variables (ANSELIN, 1988). Lagrange Multiplier tests for spatial dependence (lag and error) use first-order contiguity matrices. Significant at the ${ }^{* * *} 0.01, * * 0.05$ and $* 0.10$ levels. 
(1996-2001). The results show that model 1 is robust in the sense that the same variables are significant (and of the same sign) in models $1 \mathrm{a}$ and $1 \mathrm{~b}$.

Using model 1, all other variables were added one by one. None of these variables additionally turned out to be significantly related to employment growth except for the average wage level (model 2), business area growth (model 3), and dwellings growth (model 4). In the case of the addition of the wage level to the specification (model 2), investment was no longer significant. Model 2 suggests that employment has been created in high-wage areas. This is contradictory to the traditional expectation that low wage levels attract investment, and by doing so enhance employment growth. This outcome may reflect the higher human capital levels in high-wage regions (although the present human capital variable did not prove to be significant when added to the baseline model). High wages may also have acted as a trigger to migrate and, by doing so, raise employment/supply of labour (cf. BROERSMA and VAN Dijk, 2002). This is akin to the core mechanism explaining agglomeration in models of the new economic geography. Note that including the wage variable renders population density significant and negative (probably due to the 0.428 correlation between wages and population density). Models 3 and 4 plausibly suggest that regions where business sites or dwellings were constructed more often showed higher employment growth rates. ${ }^{4}$ The significance and sign of related variety proved to be robust over all model specifications of employment growth.

It was also tested whether employment growth is spatially autocorrelated, i.e. whether fast (slowly) growing regions are neighbours of other fast (slowly) growing regions. This was performed by computing the Lagrange Multiplier for the error term and for the spatial lag of the dependent variable in all models. Exploratory spatial analysis using Spacestat estimation software (ANSELIN, 1988) revealed that a simple contiguity matrix of adjacency between the 40 NUTS 3 regions best captures the spurious spatial dependence between regional scores. ${ }^{5}$ The dependence is spurious because the NUTS 3 level turned out to be a robust measurement level in spatial statistical terms: no variation between regional indicators can significantly be attributed to spatial correlation. In six out of seven employment growth models presented in Table 1, the Lagrange Multiplier test statistics indeed presented no significant indications for spatial lag or spatial error specifications of the models (all $p$-values are well above 0.10), which implies that the model structure and model fit do not gain from spatial error or spatial lag specifications. ${ }^{6}$

Finally, spatial dependence can occur in the independent variables of the model. Therefore, the specification in model 1 was repeated using the window average (WA) values of the independent variables. WA values are the average of the value of a NUTS 3 region and all its neighbouring regions. ${ }^{7}$ In a specification with WA variables, independent variables are measured at the supra-regional level, thus taking into account the effects of nearby regions on a region's growth (e.g. demand effects, crowding out or spillovers). From the specification including the WA variables in model 5 it can be concluded that only related variety positively affects employment growth using WA variables, while the Los-index now (unexpectedly) has a significant negative effect. The robust positive coefficient of related variety reinforces the conclusion that, as hypothesized, related variety is a main driver of employment growth.

\section{Results for productivity growth}

Table 2 provides in a similar manner as Table 1 the results for PRODUCTIVITY GROWTH as the dependent variable. Model 1 specifies the OLS baseline model, which corresponds to the baseline model for employment growth plus C-L growth. The results show that investment, $\mathrm{R} \& \mathrm{D}$, and $\mathrm{C}-\mathrm{L}$ growth are significant and positively related to regional productivity growth, as expected. Related variety is also significant, but negatively related to productivity growth. This means that whereas related variety contributed to employment growth, it slows productivity growth. The main hypothesis concerning productivity growth - localization economies enhancing productivity growth - is not confirmed since the Los-index is not significant.

Models $1 \mathrm{a}$ and $1 \mathrm{~b}$ again test for the robustness of model 1 by substituting the dependent variable, productivity growth during 1996-2001, by the same variable for different periods (1997-2001) and (1996-2000). Model 1 is not entirely robust for changes in the period of observation as investment and related variety are significant in either model $1 \mathrm{a}$ or $1 \mathrm{~b}$, but not in both. Conclusions about these two variables should therefore be drawn with care. The variables $\mathrm{R} \& \mathrm{D}$ and $\mathrm{C}-\mathrm{L}$ growth show robustness in the sense that their sign and significance remained unchanged. Again, using model 1 , all other variables were added one by one. None of these variables turned out to be significantly related to productivity growth (not shown), while the variables that were significant in Model 1 remain robust.

It was tested whether productivity growth is spatially autocorrelated by again interpreting the Lagrange Multiplier test statistics for a spatial error term and for the spatial lag of the dependent variable (again using a first-order contiguity matrix). The Lagrange Multiplier value for spatial lag is significant at the $5 \%$ level (0.038), which means that the model specification can be improved by including a spatial lag of the dependent variable, which is the average productivity growth in a region's neighbouring regions. Model 2 shows the results of the spatial lag model. Interestingly, the spatial lag of productivity growth (W_productivity growth) is significant, yet negative. This means that there is an inverse relationship between productivity growth in a region and its neighbouring regions: 
regions surrounded by low productivity growth tend to have high productivity growth and vice versa. This result underlines that the choice of NUTS 3 as the unit of analysis is justified as no positive relations can be found at the supra-regional level.

Finally, the WA specification of the baseline model (model 3) shows that R\&D and C-L growth also remain positive in that specification. As the model fit of specification 3 does not improve over specification 1 (instead, it perked down considerably), no further WA specifications were carried out.

Summarizing, most specifications show that the main drivers of productivity growth are the 'usual suspects' of $\mathrm{R} \& \mathrm{D}$ and C-L growth, both commonly associated with process innovation. Importantly, the spatial-lag results show negative spatial autocorrelation with neighbouring regions, which supports the choice of NUTS 3 regions as the relevant delineative level of analysis.

\section{Results for unemployment growth}

Table 3 provides the results for UNEMPLOYMENT GROWTH and INACTIVITY GROWTH as dependent variables. Model 1 specifies the OLS baseline model, which is equal to the baseline model for productivity but including wage as an additional control variable. From the results it can be concluded that the main hypothesis concerning unemployment growth unrelated variety is negatively related to unemployment growth - is confirmed. This means that regions with higher unrelated variety experience lower rates of unemployment growth. Furthermore, a negative significant relation is found between urbanization economies and unemployment growth. This can be explained by the fact that regions with high population densities are also regions where unemployed people have more job opportunities within commuting range (also Broersma and VAN Dijk, 2002). Urbanization economies, therefore, provide a safeguard against high unemployment growth. It was also found that regions with relative high $\mathrm{R} \& \mathrm{D}$ expenditures per fte and C-L growth experience higher unemployment growth, which suggests that some part of innovative activity is labour-saving. Finally, the expected effect of wages on unemployment was found.

Models $1 \mathrm{a}$ and $1 \mathrm{~b}$ test for the robustness of model 1 by substituting unemployment growth during 19962002 by the same variable for different periods (1997-2002) and (1996-2001). Model 1c provides an additional robustness check by using INACTIVITY GROWTH (including physically disabled besides unemployed persons) as an alternative unemployment measure for the same period. The results on robustness show that the baseline model is not entirely robust for changes in the period of observation in particular with regard to population density, unrelated variety and C-L growth. In the 1996-2001 specification (1a) neither unrelated variety nor control variables is attached to unemployment growth. Note that unrelated variety, which is of main interest to the present analysis of portfolio effects, is significant in model 1c. As for the regressions on employment growth and productivity growth, the baseline model 1 was used to add the other dependent variables one by one. None of these variables proved to be significantly related to unemployment growth (at the 5\% significance level).

It is of no help to include a spatial error or spatial lag specification of the dependent variable: the Lagrange Multiplier test statistics never suggest so. Finally, the WA specification of the baseline model (specification 2) shows that, when assuming that neighbouring regions affect a region's unemployment, population density and investment prove to counteract unemployment growth, while high wages and the Los-index enhance unemployment growth.

Summarizing, in three out of five model specifications evidence has been found that unrelated variety counteracts unemployment growth as portfolio theory predicts. The effects of control variables are not entirely robust, although the positive effect of high wages on unemployment is, as expected, significant in most model specifications. In addition, the negative effect of population density on unemployment (urbanization economies) is evident in four out of five models, which suggests that large cities provide more opportunities for unemployed people.

\section{CONCLUSIONS AND POLICY IMPLICATIONS}

The goal of this study has been to analyse the effects of variety on regional economic growth. The main contribution has been to distinguish between unrelated and related varieties. Unrelated variety is measured at the two-digit sector level; related variety is measured at the five-digit sector level within two-digit classes. The two variables had very different effects on productivity, employment and unemployment. Previous studies measured variety only in terms of what has been called unrelated variety, and therefore ignored the important effects of related variety (GLAESER et al., 1992; Feldman and Audretsch, 1999; Van Stel and Nieuwenhuijsen, 2004). Given that these contributions were motivated by spillover theory, which is associated here with related variety, the results of previous studies may be imprecise in this respect. The measures of unrelated and related variety used here can be improved as the results remain sensitive to the given Standard Industry Classification that traditionally over emphasizes industrial sectors over service sectors. Future studies could attempt to make use of alternative sectoral aggregation schemes based on more in-depth information on relatedness and knowledge flows. ${ }^{8}$

Related variety was associated with Jacobs-type externalities arising from spillovers between sectors 
stimulating employment creation (hypothesis 1), and unrelated variety was associated with a portfolio that prevents regions from experiencing shocks in unemployment (hypothesis 3). Not only were the effects of related variety and unrelated variety taken into account, but also the effect of localization economies and urbanization economies. In particular, it was expected that localization economies, as present in specialized technological clusters, would primarily enhance productivity growth (hypothesis 2). Using the variables-related variety, unrelated variety, localization economies and urbanization economies, the present study analysed all possible sources of agglomeration economies at the regional level (NUTS 3). Control variables including investment, $\mathrm{R} \& \mathrm{D}$, capital-labour ratio growth, human capital, and wage level were also taken into account.

The empirical results showed that related variety indeed enhances employment growth (hypothesis 1), while other type of agglomeration economies are not significant. Knowing that related variety is mainly present in densely populated areas, and given that population density does not significantly affect employment growth, it can be concluded that related variety in cities is responsible for job creation and not urban density in itself. From this, it can be concluded that Jacobs externalities are an important driver of employment growth. This outcome is also in line with evolutionary economics and urban lifecycle theory that predict new employment stemming from product innovation and new firm creation will emerge in diversified cities, while labour-saving productivity growth is more likely to be realized by large established firms located in more rural areas.

It was also found that unrelated variety is indeed negatively related to unemployment growth, meaning that the presence of unrelated sectors in a region acts as a portfolio against unemployment shocks (hypothesis 3). Higher wages, as expected, enhance unemployment growth; while population density retards unemployment growth. Using statistical robustness techniques, the results on unemployment were shown not to be entirely robust. Concerning productivity growth, more 'classical' results were obtained with investment, R\&D and C-L growth being the drivers behind productivity increases. The effect of localization economies on productivity growth (hypothesis 2) could not be supported.

From this study, and given statistical error, it follows that employment policy should stimulate related variety, e.g. by enhancing niche creation and spin-off firms, rather than by selecting one particular (new) sector (also Raspe and VAN OORT, 2006). ${ }^{9}$

Regional policies based on supporting related variety reduce the risk of selecting wrong activities because one takes existing regional competences as building blocks to broaden the economic base of the region. At the same time, such a policy could still acknowledge the fact that generic technologies (such as information and communication technology) may have a huge and pervasive impact on economic development in many regions due to the many potential fields of application. A regional related-variety policy combines the advantages of specialization in related activities, and is to be supplemented by national policies on generic technologies.

Acknowledgements - This research was funded by the Ministry of Economic Affairs, the Netherlands, as part of a research programme on 'Space and Productivity'. The authors thank Herm van der Beek, Ron Boschma, Stefano Breschi, Paul Cheshire, Henri de Groot and Jacco Hakfoort for helpful comments on earlier versions of the paper. They also thank Bart Los for the data on technological similarity between sectors. The usual caveats apply.

\section{NOTES}

1. For a review of empirical studies on variety and regional growth, see Dissart (2003) and Frenken et al. (2004).

2. Outliers were identified by initial $z$-values $>3$ in absolute terms. Corrections were carried out by: (1) in a first stage excluding the outlier when computing $z$-values - allowing variation in the remaining non-outlier observations; and (2) in a second stage incorporating the outliers with a relative high value in the data set (the outliers do measure reality, and should not be completely excluded from analyses).

3. The regressions with the specialization measure proposed by GLAESER et al. (1992) were also run using a classification into four sectors: industrial activities; distribution and transport services; consumer services; and producer services. These measures never turned out to be significant (FRENKEN et al. 2004).

4. This may point to endogeneity.

5. Sensitivity was also tested for higher-order contiguity spatial dependence and for first- and second-order inverse distance weights using physical distances $(\mathrm{km})-$ and none of these spatial weight formulations captured spatial dependence significantly better.

6. According to the Lagrange Multiplier test for spatial lag dependence, a spatial lag specification of model (2) in Table 1 would be appropriate. However, such a model suffers from heteroskedasticity, for which no appropriate instruments could be constructed.

7. The first-order contiguity matrix was used to calculate WA values in Spacestat (ANSELIN, 1988). It is important to note though that the window average of entropy values (used to indicate unrelated and related variety) and the Los-index cannot be computed as the average of a region and its neighbours because these indices reflect a qualitative state of the economy rather than a quantitative value. When distributions are aggregated across regions, the window average entropy is to be computed from the newly obtained frequency distribution at the supraregional level.

8. Methodological progress in measures of variety and relatedness has been made by SIEgEL et al. (1995), Verspagen (1997), Wagner (2000), and Breschi et al. (2003). These methodologies, however, are demanding in terms of the data required.

9. The authors recognize that related variety creates more knowledge spillovers in some sectors than in others. 


\section{REFERENCES}

AnSELIn L. (1988) Spatial Econometrics: Methods and Models, Kluwer, Dordrecht.

Attaran M. (1986) Industrial diversity and economic performance in U. S. areas, Annals of Regional Science 20, 44-54.

Bongaerts D., Cörvers F. and Hensen M. (2004) The Delineation and Coherence of Functional and Administrative Regions in the Netherlands, Ministry of Economic Affairs, The Hague.

Breschi S., Lissoni F. and Malerba F. (2003) Knowledge-relatedness in firm technological diversification, Research Policy 32 , 69-87.

Broersma L. and Ooster haven J. (2004) Regionale Arbeidsproductiviteit: Niveau, groei en verklaring, Ministry of Economic Affairs, The Hague (available at: http://www.minez.nl).

Broersma L. and Van Dijk J. (2002) Regional labour market dynamics in the Netherlands, Papers in Regional Science 81, $343-364$.

Dissart J. C. (2003) Regional economic diversity and regional economic stability: research results and agenda, International Regional Science Review 26, 423-446.

Feldman M. P. and Audretsch D. B. (1999) Innovation in cities: science-based diversity, specialization and localized competition, European Economic Review 43, 409-429.

Feser E. J. (2002) Tracing the sources of local external economies, Urban Studies 39, 2485-2506.

Frenken K., Van Oort F. G., Verburg T. and Boschma R. A. (2004) Variety and Regional Economic Growth in the Netherlands, Ministry of Economic Affairs, The Hague (available at: http://www.minez.nl).

Glaeser E. L., Kallal H., Scheinkman J. and Shleifer A. (1992) Growth in cities, Journal of Political Economy 100, $1126-1152$.

HAUG P. (2004) Diversifikation und regionale Wirtschafts- und Beschäftigungsentwicklung. Eine empirische Analyse für ausgewählte deutsche Gebiete, Review of Regional Research 24, 177-195.

Henderson J. V. (2003) Marshall's scale economies, Journal of Urban Economics 53, 1-28.

Jacobs J. (1969) The Economy of Cities, Vintage, New York, NY.

JACQUEmin A. P. and BerRy C. H. (1979) Entropy measure of diversification and corporate growth, Journal of Industrial Economics 27, 359-369.

Jaffe A. B. (1986) Technological opportunity and spillovers of R\&D, American Economic Review 76, 984-1001.

Kim S. J. (1997) Productivity of Cities, Ashgate, Aldershot.

Kort J. R. (1981) Regional economic instability and industrial diversification in the U. S., Land Economics 57, 596-608.

KRUgman P. R. (1991) Increasing returns and economic geography, Journal of Political Economy 99, 483-499.

Krugman P. R. (1993) Lessons of Massachusetts for EMU, in Torres F. and Giavazzi F. (Eds) Adjustment and Growth in the European Monetary Union, pp. 241-269, Cambridge University Press, Cambridge.

Los B. (2000) The empirical performance of a new inter-industry technology spillover measure, in SAVIOTTI P. P. and Noотевоом B. (Eds) Technology and Knowledge, pp. 118-151, Edward Elgar, Cheltenham.

Montgomery C. A. (1994) Corporate diversification, Journal of Economic Perspectives 8, 163-178.

Pasinetti L. L. (1993) Structural Economic Dynamics, Cambridge University Press, Cambridge.

Quigly J. M. (1998) Urban diversity and economic growth, Journal of Economic Perspectives 12, 127-138.

Raspe O. and Van Oort F. (2006) The knowledge economy and urban economic growth, European Planning Studies 14, 1209-1234.

Saviotti P. P. and Pyka A. (2004) Economic development by the creation of new sectors, Journal of Evolutionary Economics 14, $1-35$.

Siegel P. B., Johnson T. G. and Alwang J. (1995) Regional economic diversity and diversification, Growth and Change 26, $261-285$.

Solow R. M. (1957) Technical change and the aggregate production function, Review of Economics and Statistics 39, 312-320.

Teece D. J., Rumelt R., Dosi G. and Winter S. G. (1994) Understanding corporate coherence: theory and evidence, Journal of Economic Behaviour Organisation 23, 1-30.

Theil H. (1972) Statistical Decomposition Analysis, North-Holland, Amsterdam.

Van Oort F. G. (2004) Urban Growth and Innovation. Spatially Bounded Externalities in the Netherlands, Ashgate, Aldershot.

VAn Stel A. J. and Nieuwenhuijsen H. R. (2004) Knowledge spillovers and economic growth: an analysis using data of Dutch regions in the period 1987-1995, Regional Studies 38, 393-407.

VERNON R. (1966) International investment and international trade in the product lifecycle, Quarterly Journal of Economics 80, 190-207.

VERSPAGEN B. (1997) Measuring inter-sectoral technology spillovers: estimates from the European and US patent office databases, Economic Systems Research 9, 49-67.

Wagner J. E. (2000), Regional economic diversity: action, concept, or state of confusion, Journal of Regional Analysis and Policy 30, 1-22.

WAsylenko M. J. and ERickson R. A. (1978) On measuring economic diversification: comment, Land Economics 54, 106-110. 